\title{
Savithri Scale for New Malay Gamelan
}

\author{
Muhammad Al-Hafiz Bin Mohd Nur Helmi Chai \\ Faculty of Applied and Creative Art \\ Universiti Malaysia Sarawak
}

\author{
Yoesbar Djaelani \\ Faculty of Applied and Creative Art \\ Universiti Malaysia Sarawak
}

\begin{abstract}
An experimental research meant to explore Malaysian gamelan to another level. By implementing purposive sampling in methodology, researcher chose Savithri scale to apply in ethnomusicology studies and producing three sets of new Malay gamelan piece way different than the original pentatonic scale of traditional Malay gamelan.
\end{abstract}

Keywords:- Malay Gamelan; New Gamelan; Pentatonic Scale; Savithri Scale; Variation.

\section{INTRODUCTION}

\section{Malay Gamelan}

Malay gamelan, also known as Terengganu gamelan is the most common gamelan ensemble in Malaysia consists of seven main instruments, namely, saron peking, saron baron, saron demung, bonang, gambang, kenong and gong (Matusky, 2008). Traditionally, gamelan is only played on certain occasions such as ritual ceremonies, puppet shows, royal celebrations and cultural dance. Today, gamelan is also successfully expanded in music concert as well as social gathering to welcome guests. Gamelan also penetrates various art disciplines including traditional and modern dance, as well as drama and theatre (Wong, 2016).

\section{Savithri Scale}

The notation of Raga is referred to as Swar. Swar consists of seven notations from the scale of Indian music. Basically, Swar is similar to solfege in Western music theory. The seven Swars are referred to as, Shadaj (Sa), Rishabh (Re), Gandhara (Ga), Madhyam (Ma), Pancham (Pa), Dhaivat (Da) and Nishad (Ni). However, (Sa, Re, Ga, Ma, $\mathrm{Pa}, \mathrm{Da}, \mathrm{Ni}$ ) acronym is the most commonly used. It is called Sargam (Courtney, 1995).

Raga also has a mode structure (Bose, 1960). It is referred to as Thaat in Northern Indian music and Mela in Southern India music. Among the Thaat identified are;

\begin{tabular}{|c|c|c|}
\hline Thaat & Equivalent & Interval \\
\hline Bilawal & Ionian & $1,2,3,4,5,6,7$ \\
\hline Kafi & Dorian & $1,2,3 \mathrm{~b}, 4,5,6$, \\
& & $7 \mathrm{~b}$ \\
\hline Asawari & Aeolian & $\begin{array}{c}1,2,3 \mathrm{~b}, 4,5,6 \mathrm{~b}, \\
7 \mathrm{~b}\end{array}$ \\
\hline Bhairavi & Phrygian & $\begin{array}{c}1,2 \mathrm{~b}, 3 \mathrm{~b}, 4,5,6 \mathrm{~b}, \\
7 \mathrm{~b}\end{array}$ \\
\hline Kalyan & Lydian & $1,2,3,4 \#, 5,6,7$ \\
\hline Savithri & Mixolydian & $1,2,3,4,5,6,7 \mathrm{~b}$ \\
\hline Bhairav & & $1,2 \mathrm{~b}, 3,4,5,6 \mathrm{~b}$, \\
& & 7 \\
\hline Marwa & & $1,2 \mathrm{~b}, 3,4 \#, 5,6$, \\
& & $1,2 \mathrm{~b}, 3,4 \#, 5,6 \mathrm{~b}$, \\
\hline Purvi & & $1,2 \mathrm{~b}, 3 \mathrm{~b}, 4 \#, 5$, \\
& & $6 \mathrm{~b}, 7$ \\
\hline Todi & & $\mathrm{Raga}$ \\
\hline
\end{tabular}

Table 1:- Mode Structure in Raga

\section{BACKGROUND}

There are lack of variation in Malaysian gamelan scale. So far, Malaysia has just two types of gamelan, namely, Terengganu gamelan scale $(1,2,3,5,6)$ and Javanese gamelan scale $(1,3,4,5,7)$. Thus, the objective of this study is to produce three sets of new Malay gamelan piece in the scale of Savithri $(1,2,3,4,5,6,7 \mathrm{~b})$ to add variety in the Malaysian gamelan scale.

The importance of this study is closely related to researcher's idealistic vision for diversifying gamelan variation in Malaysia. In addition, this study can show the community about Indian Raga and its close association with Malay music.

\section{METHODOLOGY}

Savithri scale was chose out of ten Thaat in Raga mode structure (Bose, 1960) through purposive sampling.

Researcher also used purposive sampling in determining data that later to be analyzed as a guide to produce new Malay gamelan piece in Savithri scale. Data were taken from 'Malaysia Merdu' (1993) album and 'Senandung Warisan' music book (Arkib Negara Malaysia, 2004). 
ISSN No:-2456-2165

The objectives of the data are to prove that classic Malay songs were already formed by Savithri scale and to justify the usage of Savithri scale in new Malay gamelan creation.

\section{RESULTS AND FINDING}

Researcher found frequent use of flat-seventh (bVII) chord and notation in classic Malay songs. It is equivalent to Mixolydian mode and truly fits Savithri scale. Every flatseventh notation in the diagram are notated in red.
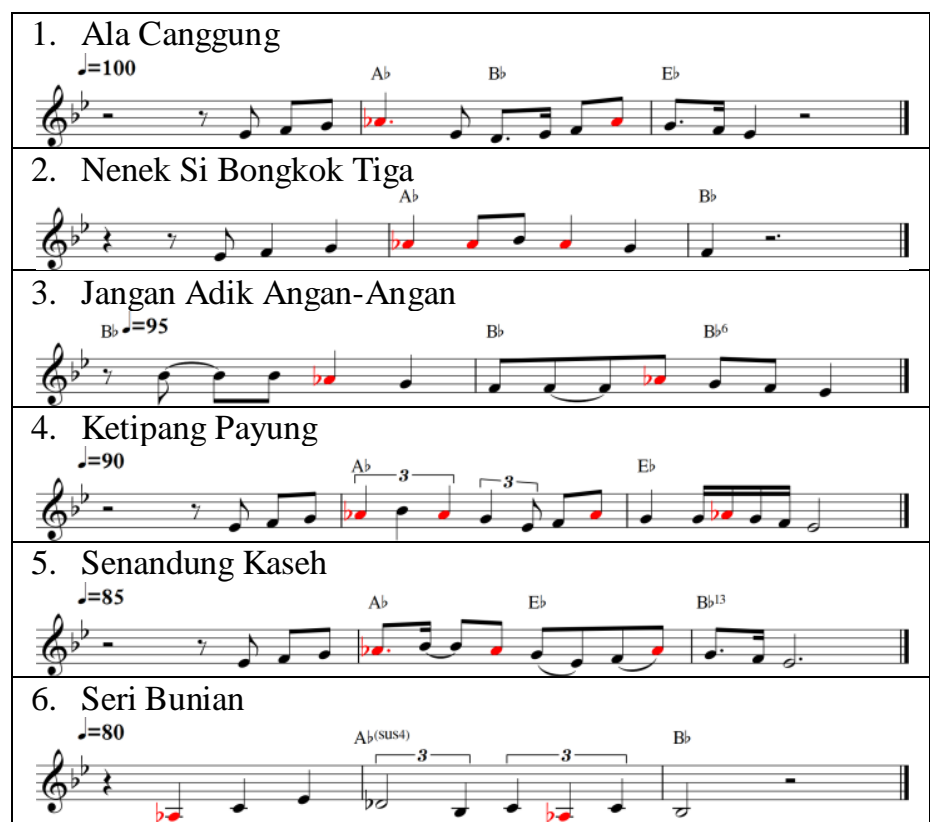

Table 2:- Data Analysis

These data analysis were used as a guide to compose three set of new Malay gamelan motives in Savithri scale. Every flat-seventh notation in the diagram are notated in red.
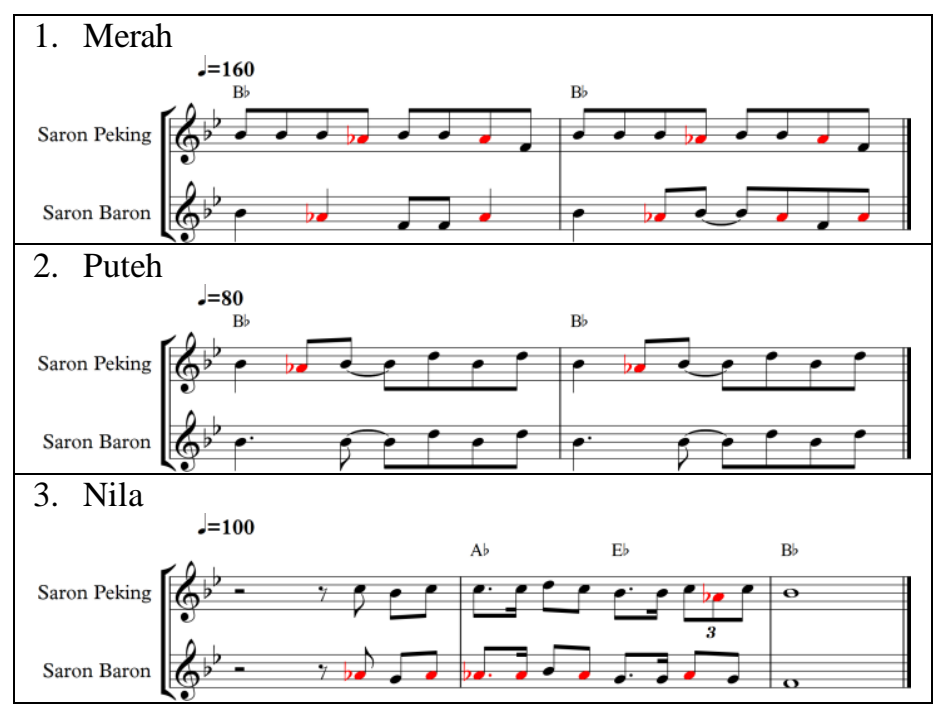

Table 3:- New Malay Gamelan Motives

\section{DISCUSSION AND CONCLUSION}

Researcher had interviewed Mr. Thomas Lamada; a gamelan expert from Universiti Malaysia Sarawak Cultural Association (BAYU) on the effectiveness and appropriateness of Savithri scale application for new Malay gamelan.

He said that this research is a great innovation to spark interest and increase the variation of gamelan music in Malaysia. He also added, the suitability of Savithri scale depends on the type of song and its use. Researcher agreed with his opinion.

Mr. Thomas Lamada recommended; if new Malay gamelan in Savithri scale is successfully invented, the traditional music practitioner can already play existing Savithri scale Malay songs on it. Both traditional and contemporary music composers can also begin to create songs for this new Malay gamelan.

To conclude, researcher suggested that this idea to be welcomed by government agencies with funds allocation to produce physical set of new Malay gamelan in Savithri scale as it will be a game-changer and varies gamelan music in Malaysia.

\section{REFERENCES}

[1]. Arkib Negara Malaysia. (2004). Senandung Warisan. Kuala Lumpur: Arkib Negara Malaysia.

[2]. Bose, K. (1960). Melodic Types of Hindustan. Bombay: Jaico Publishing.

[3]. Courtney, D.C. (1995). Elementary North Indian Vocal Volume 1. Houston TX: Sur Sangeet Services.

[4]. Matusky, P.Y. (2008). Aspect of BasicInstrumentation and Traditional Form of Repertoir of Malay Gamelan and The Challenge of Repertoir Expension. Terengganu: World Gamelan Symposium and Festival.

[5]. Wong, Y.S. (2016). Gamelan Melayu: New Instrumentation Setup in the Ensemble. Kuala Lumpur: University of Malaya. 